und der Vorsitzende der PD, Emil Boc, warnte vor "gefährlichen Präzedenzfällen «. ${ }^{63}$

In der Krise um György Frunda spiegelt sich das Dilemma des rumänischen Ungarnverbands, der Erfolge verbuchen muss, um gegen seine politischen Konkurrenten zu punkten. Die

63 O.N.: Az SZDP szerint az EMNT a »Magyar Irredentizmus Tanácsa « [Die PSD betrachtet den EMNT als »Rat des ungarischen Irredentismus «], in: Romániai Magyar Szó, 18.12.2003.
Fundamentalopposition, die ihm in der Regierungskoalition aus den Reihen der PD entgegenschlägt, lässt derzeit eher Neuwahlen als einen Kompromiss wahrscheinlich erscheinen. Sollten sich die radikalen ungarischen Vertreter bei einer Parlamentswahl gegen den RMDSZ etablieren können oder dazu beitragen, dass keine der ungarischen Organisationen mehr im Parlament vertreten sein wird, dürfte dies die Konfliktlage in Rumänien verschärfen.

FOR U M

\title{
In the Name of the Pater, or Why Democracy Remains Absent from Central Asia
}

\author{
Klavdija Černilogar*
}

\begin{abstract}
The independence of the Central Asian countries has not been accompanied by transition towards democracy. This process is prevented through the dominance of neopatrimonial patterns of governance, which combine new formally existing democratic institutions and the traditional persistence of the patrimonial system of rule. Two basic characteristics of this type of rule are its rootedness in the traditional societal structure and the misuse of the imprecise legal framework. The international community's attempts to contribute to the democratisation of Central Asia are largely unsuccessful and will remain so until there is clear domestic preparedness for reform.
\end{abstract}

Keywords: Central Asia, neopatrimonialism, democracy

Contrary to nationalist movements that resulted in the establishment of independent states in Central and Eastern Europe in the early 1990s, the independence of Central Asian states was not strived for from within; instead, it was the consequence of the Soviet Union's dissolution. After the change, it was no longer enough for the incumbents to please Russia to stay in power; now they had to secure their political existence on their own. ${ }^{1}$ Kazakhstan's and Uzbekistan's presidents have extended their mandates through nation-wide referenda. In short, they have managed to manipulate the existing procedural options to serve their personal interests. In the 15 years of independence of the five Central Asian countries, practically only five presidents have ruled there. Three state presidents - the Kazakh Nursultan Nazarbayev, the Uzbek Islam Karimov, and the Turkmen Saparmurat Niyazov - have been heads of their republics since independence in 1991, coming from top positions they had occupied while still in the Soviet

\footnotetext{
* Klavdija Černilogar holds the European Master's Degree in Human Rights and Democratisation, and has done her research for the Master thesis at the Institute for Peace Research and Security Policy at the University of Hamburg (IFSH). Currently, she works as intern at the Council of Europe office in Belgrade

1 Anatoly M. Khazanov, After the USSR. Ethnicity, Nationalism and Politics in the Commonwealth of Independent States, Madison, The University of Wisconsin Press, 1995, p. 141
}

Union. Tajikistan's head Emomali Rahmonov has been in office since 1992, although formally elected as president only in 1994, and the president of Kyrgyzstan Askar Akayev ruled between 1991 and $2005 .^{2}$

Having become part of the international community as sovereign states, the five Central Asian countries formally accepted democratic standards, including those of free and fair elections, at least as members of the United Nations and the Organization for Security and Co-operation in Europe. The latter has conducted several election observation missions in all but Turkmenistan, and has repeatedly concluded that the elections were not in accordance with its commitments. Other outside assistance on the way to democratisation, offered by countries as well as international governmental and non-governmental organisations, also seems to be in vain. Why are external efforts fruitless? Why does the rule of the pater persist? We will attempt to answer these two questions below; the former through a theoretical approach to democratisation, the latter through an analysis of the Central Asian political environment.

2 For details on the political background of individual presidents, see Martha B. Olcott, Taking Stock of Central Asia, in "Journal of International Affairs", vol. 56 , no. 2, 2003, pp. 8-9. 


\section{The demand or the supply - which is the driving force behind democratisation?}

The question which actors - the domestic or the international - play a larger role in the process of democratisation of a country is subject to various explanations within the theoretical and the political realms. It is often argued that unless the domestic climate works favourably towards democratisation, all external endeavours will be in vain. According to Reilly, Western input into a country in democratic transition has a limited range: it can help design and construct stable institutions, provide security and required infrastructure, and assist in formulating norms and procedures for the initial attempt of a democratic election. From that point onwards, »democracy is a domestic game ${ }^{3}{ }^{3}$ Schmitter and Brouwer agree: external impact on democratisation is marginal and only as effective as domestic actors allow it to be. Furthermore, there should not be too much external interference, they claim, otherwise domestic actors will feel detached from the process and will not internalise its effects. Democracy promotion and protection should in their view be »self-cancelling « policy instruments. ${ }^{4}$ Geiss addresses the question specifically in relation to Central Asia. He maintains that the reform of these countries political systems can only be done by domestic political elites. The influence of external actors can function as an additional support of the reforms at the utmost. ${ }^{5}$ Even more radical is the view of the former president of Kyrgyzstan, Akayev. In an interview he stated that »the genuine power of the people should grow within the countries themselves. [...] Pushing this process from the outside as a kind of »export of democracy « strongly resembles the Bolshevik 'export of revolution' «. ${ }^{6}$ Less extreme, yet still suspicious of international efforts, is Esenov. He believes it is unreasonable for democratising countries in Central Asia to accept all recommendations offered by the West, because "nobody knows the situation here better than we do «?

The principles of sovereign equality of states and of non-interference in their internal affairs remain major characteristics of contemporary international relations. Therefore, advocates of the idea that democratisation cannot come into being without help from outside are understandably less ardent than the supporters of the primacy of domestic efforts. In one of his earlier writings, Schmitter supposes that countries which had no democratic tradition before becoming sovereign would generally rely on external assistance on their way to democracy. In his view, this holds for Central Asian countries as well.

3 Benjamin Reilly, International Electoral Assistance. A Review of Donor Activities and Lessons Learned, Working Paper 17, The Hague, Netherlands Institute of International Relations »Clingendael «, 2003, p. 25.

4 Philippe C. Schmitter, Imco Brouwer, Conceptualising Researching and Evaluating Democracy Promotion and Protection, EUI Working Paper SPS no. 99/9, Florence, European University Institute, 1999, pp. 11-12. See also Armin K. Nolting, External Actors in Democratisation Processes: The European Union and Its Activities in Southern Africa, Bochum, Institute for Development Research and Development Policy, 1999, p. 3.

5 Paul G. Geiss, Demokratisierung und gesellschaftliche Reformen in Zentralasien, Bonn, Friedrich-Ebert-Stiftung, 2002, p. 11

6 Hamid Toursunof, No Exporting Democracy, Please, in »Transitions Online», 14 June 2004, at http://www.tol.cz/look/TOLrus/article.tpl?IdLanguage=1\& IdPublication $=4 \&$ NrIssue $=68 \&$ NrSection $=1 \&$ NrArticle $=12247$.

7 Yekaterina Luzanova, Murad Esenov: Nobody Knows the Central Asian Situation Better Than We, in »The Central Asian Post«, 20 November 1997, at http:// www.ca-c.org/dataeng/Esenov2.shtml.
Still, Schmitter does not forget to underline that the principal domestic actors who should welcome international support - the political leaders - may be more concerned with how to secure re-election than with slow and long-term processes of democratisation. He sees importance in external pressure insofar as it represents an incentive for the rulers to keep the pace of reform. ${ }^{8}$ According to Blank, internal forces do not have the power to "make the necessary transition without foreign assistance.$^{9}$ In the same breath he adds, however, that in order for foreign help to be useful, domestic preparedness for reform is indispensable. Furthermore, in Brock et al., we find that exporting democracy is more than a response to the needs of democratising countries. It is a $»$ normal $«$ constitutive part of established democracies' foreign policies. ${ }^{10}$ The decision remains on the democratising countries whether they will see the need to welcome the exported democracy as part of their own domestic policies.

It would be futile to attempt to put domestic and international actors on a scale, according to how important a role they play in the process. Once internal and external factors come into contact, their respective activities and behaviour become intertwined. One side affects the reaction of the other. Whether a country can democratise on its own or the international community can democratise it despite its resistance are questions of "who is better than who", and do not produce useful answers. Unless both sides are committed to the same goal, little success is to be expected. Another question is what results democratisation processes bring to each of them. It is not only the target country that changes; also the assistance providers do. Countries modify their strategies, inter-governmental organisations reform, and non-governmental organisations find new niches to work in. In Central Asia, however, the domestic preparedness for reform does not seem to go beyond political declarations heard at international events. The present type of rule enables the incumbents to keep the power effectively in their hands, and prevents practically any change from the system that functioned within the Soviet Union.

\section{Neopatrimonialism: the obstacle for democrat- isation in Central Asia}

Inevitably, the last decade of political developments in Central Asia has posed the question of what kind of democratisation path these countries are following, if at all. Eager to achieve the international recognition of their place among established democracies, the Central Asian countries have in many aspects copied the constitutional and institutional framework of the Western world. Yet the implementation is lacking, and democracy has not (yet) become firmly anchored in their political culture. Schmitter predicts the per-

8 Philippe C. Schmitter, Dangers and Dilemmas of Democracy, in Larry Diamond, Marc F. Plattner (eds.), The Global Resurgence of Democracy, Baltimore, The Johns Hopkins University Press, 1996, p. 84

9 Stephen Blank, Democratic Prospects in Central Asia, in »World Affairs«, vol. 166, no. 3, 2004, p. 133.

10 Lothar Brock et al., Kernprojekt III/1: Demokratieförderung als Risikostrategie: Die Demokratisierungspolitik der Demokratien, Frankfurt am Main, Hessische Stiftung Friedens- und Konfliktforschung, 2004, at http://www.hsfk.de/ downloads/Kernprojekt\%20III-1.pdf. 
sistence of unconsolidated democracy there, ${ }^{11}$ Colton calls the Central Asian republics pre-democracies, ${ }^{12}$ Zakaria is convinced that half of the democratising countries today are illiberal anyway, among them Kazakhstan. ${ }^{13}$ Interestingly, only one Central Asian country, Kyrgyzstan, was placed among electoral democracies in the report issued by Freedom House. Tajikistan was categorised as a country with restricted democratic practice, whereas Kazakhstan, Turkmenistan and Uzbekistan were labelled authoritarian regimes. ${ }^{14}$ Let us add that Olcott actually notes a reversal in case of Kazakhstan: its most democratic period was in the early 1990s when it was a managed democracy, where »the ruling elite set strict barriers on those engaged in independent political actions «. ${ }^{15}$ This last characterisation adequately sums up the lowest common denominator of all Central Asian political systems: as different as they are otherwise, in all of them there is a more or less tight control of the societal life by the rulers, despite the existence of constitutional and institutional bases for democracy. If these bases would be used in an inclusive sense, i.e. allowing wide popular participation, guaranteeing human rights, and holding public servants and politicians accountable to the population, then, regardless of history, culture, religion and other societal characteristics, we could detect a genuine move towards liberal democracy. Instead, in the past 15 years not much has changed in terms of who rules in Central Asia. Procedurally, elections have been conducted but the same people stay in power, more concerned about re-election than about the well-being of their voters. ${ }^{16}$ Such types of societies have flourished in many non-European countries, and have been characterised as neopatrimonial systems.

A patrimonial state is characterised by a strong leader whose legitimacy rests upon traditional loyalty of his subjects. ${ }^{17}$ Analyses of the phenomenon in traditional systems abound but contemporary authors acknowledge that patrimonial structures in a slightly modified form are no less frequent today. A patrimonial regime basically differs from a neopatrimonial one in the formal existence of democratic institutions. In a neopatrimonial state, the foundations that are required for a political system based on the rule of law, separation of powers and wide political participation, are present. Nevertheless, they are primarily used by the incumbent rulers to enhance their power and ensure re-election.

11 Philippe C. Schmitter, supra note 9, p. 80.

12 Colton distinguishes between pre-democracies, antidemocracies and protodemocracies, all three being types of transition, which evolved on the territory of the former Soviet Union. Timothy J. Colton, Politics, in Timothy J. Colton, Robert Legvold (eds.), After the Soviet Union: From Empire to Nations, New York/London, The American Assembly, 1992, p. 23.

13 Fareed Zakaria, The Rise of Illiberal Democracy, in »Foreign Affairs«, vol. 76, no. 6, 1997, p. 23.

14 Freedom House, Democracy's Century. A Survey of Global Political Change in the $20^{\text {th }}$ Century, 1999, at http://www.freedomhouse.org/research/ demcent.htm.

15 Martha B. Olcott, Kazakhstan: Unfulfilled Promise, Washington D.C., Carnegie Endowment for International Peace, 2002, p. 95.

16 For the countries' economic records see Interstate Statistical Committee of the CIS, Volume Indices of Gross Domestic Product, 2004, at http:// www.cisstat.com/eng/mac-01.htm.

17 Paul G. Geiss, Entwicklung und aktueller Stand der (Neo-)Patrimonialismusforschung unter besonderer Berücksichtigung der Erklärungskraft sowie der Desiderata dieses Ansatzes für Zentralasien bezüglich Stabilitätsstrategien und Herrschaftsformen, -instrumenten und -strukturen, Hamburg, Deutsches Orient-Institut, 2003, p. 3.
Bureaucracy and law are designed so as to enable essentially unlimited rule by the top individual. Public participation is, at best, limited because of political apathy. At worst, it is constrained by dubious procedures or by sheer manipulation of the will of the electorate. Some neopatrimonial patterns can even be observed in societies that consider themselves to be pioneers of democracy: in many countries, political leaders have the right to appoint a certain share of personally chosen staff to sensitive positions. In the USA, for example, about 3,000 governmental posts can be filled by politically selected individuals. ${ }^{18}$

In Central Asia as well, it is the symbiosis of the traditional patrimonial rule and modern bureaucratic institutions that denotes the neopatrimonial system. ${ }^{19}$ Using Fisun's typology, the Tajik neopatrimonial rule is oligarchic; it is based on clientelistic networks of patronage where oligarchic and/ or regional actors act together with or in place of governmental institutions. The Kazakh, Kyrgyz, Uzbek and Turkmen versions of neopatrimonialism can be characterised as sultanic and their distinguishing marks are extreme concentration of power, pure personal rulership, façade elections, and clan models of voting. What differentiates Kazakhstan and Kyrgyzstan from Uzbekistan and Turkmenistan is the level of public competition of elites. While the first two can be said to have a semi-competitive regime, Uzbekistan and Turkmenistan are classified as a low-competitive ones. ${ }^{20}$ Two basic aspects thus enable the pater to persevere in the Central Asian environment: the societal conditions and the way in which constitutional and legal stipulations are manipulated.

\subsection{The societal basis of neopatrimonialism}

It is to be noted that Central Asian countries have not had the experience of national statehood before they were faced with the dissolution of the Soviet Union. True, they are named after the predominant ethnic groups but there is no clear national homogeneity, with the exception of Turkmenistan and Uzbekistan. Having no obvious national identity makes it very difficult to sustain stability within the state. The presidents have chosen to avoid the trouble of satisfying the interests of all groups and preventing conflict in a liberal democratic manner. To remain in power, they rule with a more or less firm hand (former Kyrgyzstan's president being judged the least and the Turkmenistan incumbent the most authoritarian). A useful way to divert popular attention from their virtually never-ending rule and to awaken some sort of partial national unity is, for example, to point

18 Derick W. Brinkerhoff, Arthur A. Goldsmith (eds.), Clientelism, Patrimonialism and Democratic Governance: An Overview and Framework for Assessment and Programming, Cambridge, Abt Associates Inc., 2002, p. 8.

19 Oleksandr Fisun, Developing Democracy or Competitive Neopatrimonialism? The Political Regime of Ukraine in Comparative Perspective, Workshop presentation, Toronto, Centre for Russian and East European Studies, 2003, p. 3, at http:// www.utoronto.ca/jacyk/Fisun-CREES-workshop.pdf.

20 Idem, p. 6. 
against the Russian population rather than being inclusive towards it. ${ }^{21}$

Further, more important distinctions exist within ethnic groups, be they parochial, regional, tribal and/or clanal. ${ }^{22}$ These cleavages are reflected in the structure of the political leadership as well. Usually, the ruling presidents give important positions to family and clan members, and similarly, local leaders put »their « people in local administration posts. Retaining support of one's local environment may thus be of utmost importance, ${ }^{23}$ while keeping a good profile in the eyes of the central ruling elite is none the less crucial. The everpresent fear from popular revolt forces the heads of Central Asian countries to seek support in their own base to secure their positions in the next term in office. Such a system creates a vicious circle of mutual interdependence on the local level, as well as between lower levels and the centre. Staying in power means retaining economic benefits for the family/ clan/tribe, and that is why it is not difficult to understand why incumbents make sure they will keep top positions. Most likely they will have tailored procedural rules to achieve it, e.g. by passing appropriate laws; if not, electoral fraud will help obtain the desired result and/or threats and incentives will be employed. It is widely reported that during election campaigns candidates often resort to bribery, corruption and electoral fraud, and the authorities control the election administration and/or otherwise arbitrarily interfere in the electoral process. ${ }^{24}$

Such strong identification with one's reference group does not help overcome divisions within a nation, and further supports the rulers' inclination to authoritarianism. In an environment where the rational bureaucratic rule does not function, there is no clear division of private from public sphere and this does not lead towards consolidated democracy. ${ }^{25}$ In their presidents' views, people of Central Asia are »incapable of sharing power in a harmonious fashion $\ll{ }^{26}$ Also, the intrinsic values of Central Asian societies - loyalty, traditionalism, and inclination to personal and social obligations - have

21 Ian Bremmer, Nation- and State-Building in Eurasia, in »Georgetown Journal of International Affairs«, vol. 4, no. 1, 2003, p. 34. Russians have become second-class citizens, they have lost political weight, which they - mostly immigrants - had enjoyed in Soviet times. The sudden overturn to building an »own« nation has led to increased »nativisation of culture and administration «, to the detriment of minorities in general, Hunter explains. See Shireen T. Hunter, Central Asia Since Independence, Westport/London, Praeger, 1996, p. 34.

22 Regional divisions are overt in Kyrgyzstan: the North is more Russified and European, the South more religious and traditional. Loyalty and personalist relationships on the national basis can be observed in Uzbekistan. Internationally, personalised politics is obvious as well since foreign policy is the domain of presidents. Relationships between Central Asian leaders demonstrate constant fluctuation between eternal friendship and persistent opposition. See Rainer Hermann, Konfliktkonstellationen in Zentralasien - Herausforderungen für die OSZE, in »OSZE Jahrbuch«, Baden-Baden, Nomos Verlaggesellschaft, 2001, p. 205.

23 For individual cases in Kyrgyzstan, see International Crisis Group, Political Transition in Kyrgyzstan, Problems and Prospects, Asia Report no. 81, Osh/Brussels, ICG, 2004.

24 Cases of deregistered candidates and unclear complaint procedures appear in abundance in every OSCE/ODIHR election observation report from Central Asia. Similarly, incomplete voter lists, bribery of voters or manipulation of polling results, constitute common practice.

25 Guillermo O'Donnell, Counterpoints: Selected Essays on Authoritarianism and Democratisation, Notre Dame, University of Notre Dame Press, 1999, pp. $180-182$

26 Martha B. Olcott, Revisiting the Twelve Myths of Central Asia, Working Papers, Washington D.C., Carnegie Endowment for International Peace, 2001, p. 17. impeded the true flourishing of democracy. ${ }^{27}$ However, it is not culturally inherent in any nation to accept suppression and succumb to the interests of the few, and a general acceptance of the »iron hand [...] does not mean that they have a cultural affinity toward dictatorship « ${ }^{28}$ There will always be opposition, waiting for the right moment to come up, like in March 2005 in Kyrgyzstan, and to a less successful extent in May 2005 in Uzbekistan. The Kyrgyz and Uzbek uprisings confirm Olcott's rejection of the Central Asian people's »cultural affinity toward dictatorship «. The different outcomes of the revolts rather point to the level of authoritarianism, which in Uzbekistan this time still managed to suppress the voice of the opposition.

\subsection{Misuse of the imprecise legal framework}

Despite existing institutions, neopatrimonial systems lack most characteristics of the rational bureaucratic system: predictability, neutrality, transparency, among others. ${ }^{29}$ The problem does not lie so much in outright breaches of law by the authorities as in the vagueness of the legal framework and the procedures that it allows, giving particularly extensive powers to the executive.

Following this line of thought, it is not surprising to see that all five Central Asian states have strong presidential regimes with low degrees of parliamentary powers. In all of them there is a clear lack of balance between political institutions, and the power remains in the hands of the presidents and their closest administrations. Parliaments play a minor role; their competences do not reach much farther than to formally acknowledge or reject presidential decisions. We can observe how the institutions seem to embody democratic principles, but they do not work in that manner. More than the formal rules, the informal character of governance directs the conduct of dayto-day business. ${ }^{30}$ In such societies there is a lack of clarity and transparency in public affairs, and accountability is practically non-existent. In Central Asia the incumbent presidents behave as omnipotent and immortal, and formal succession processes are either weak or not constitutionally guaranteed at all. For example, the Turkmen and Uzbek constitutions only regulate the procedure for substitution in case of the president's temporary incapacity but not in case of death. ${ }^{31}$

Notwithstanding its negative sides, this institutional dualism, which permits floating between formal and informal rules, persists because there are some important »latent functions « it performs for the society. Informal - neopatrimonial - patterns allow the integration of ordinary citizens in public life, albeit through personal connections. Also, by resorting to informal

27 Gregory Gleason, »Asian Values « and the Democratic Transition in Central Asia, in »Harvard Asia Quarterly«, vol. 5, no. 1, 2001, at http://www.fas.harvard.edu/ asiactr/haq/200101/0101a002.htm.

28 Martha B. Olcott, supra note 27, p. 17

29 For a comparison between patrimonial and rational bureaucratic systems, see Derick W. Brinkerhoff, Arthur A. Goldsmith, supra note 19.

30 Derick W. Brinkerhoff, Arthur A. Goldsmith, supra note 19, pp. 1-2. The authors explain the co-existence of formal and informal rules through the historical evolution of the relationship between the rulers and the ruled, from tribal communities, over feudalism, absolutism, to the nation state of today.

31 Martha B. Olcott, supra note 27, p. 10. 
contacts with politicians, people often achieve their goals faster and more effectively than through formal bureaucratic tenders. ${ }^{32}$

It is difficult to say with certainty when such ambiguous actions have breached the law and when they have merely used the legal vacuum. Constitutional and legislative stipulations are in many instances formulated in so vague terms that various interpretations are possible. Usually they will be used by the ones in power - either to reinforce their position or to weaken the opposition. Let us look at some cases in the field of elections. Setting conditions for individuals to register as candidates in Kyrgyzstan is one example. Candidates running for parliamentary positions need to fulfil the constitutional condition which requires a permanent in-country residence of five years before nomination. ${ }^{33}$ In Uzbekistan the constitution requires a ten-year permanent residence in the country immediately prior to elections. ${ }^{34}$ This effectively prevents active diplomats and young intellectuals working outside from running for important positions at home, and leaves the domestic elite »safe « from people who might bring in new ideas. Furthermore, candidates and political parties may be de-registered for minor technical violations, depending on the judgement of electoral commissions, because registration provisions are formulated in ambiguous terms. ${ }^{35}$ In terms of voting rights, Kyrgyzstan also offers an example. At the 2005 parliamentary elections the Parliament decided not to allow the Kyrgyzs abroad to cast their vote. The decision itself was not in contravention to the Election Code because the law in fact regulates out-of-country voting only for presidential elections - the problem is that it is silent on parliamentary ones. ${ }^{36}$

How law can actually support the existing power structures and how free the authorities are to bend rules to correspond to their interests was demonstrated by a recent case in Kazakhstan. After the Kyrgyz opposition had achieved the change on top of the country in spring 2005, the Kazakh authorities began with a campaign to restrict fundamental freedoms,

32 Robert K. Merton, cit. in Derick W. Brinkerhoff, Arthur A. Goldsmith, supra note 19 , pp. 9-10.

33 Constitution of the Kyrgyz Republic, adopted 5 May 1993, Art. 56(1).

34 The Constitution of the Republic of Uzbekistan, adopted 8 December 1992, Art. 90.

35 See for example OSCE/ODIHR, Parliamentary Elections, The Kyrgyz Republic, 27 February 2005, International Election Observation Mission, Statement of Preliminary Findings and Conclusions, Bishkek, OSCE/ODIHR, 28 February 2005, p. 5.

36 Idem, p. 7 with the obvious intent of preventing similar developments at home. The Election Law has been amended to ban public demonstrations between the end of an election campaign and the announcement of election results, and has introduced more restrictions on the timing for the registration of candidates. In addition, the parliament began considering a draft law that would significantly restrict the work of foreign nongovernmental organizations in the country. An amendment to the national security law has been passed, which, among other restrictions, prohibits activity by foreigners, foreign legal entities, and international organizations that might interfere with the outcome of elections. ${ }^{37}$

\section{Conclusion}

The situation of state affairs in Central Asia, briefly sketched above, does not give hope for change towards democracy, rule of law and respect for human rights any time soon. The efforts of international actors do not find a sufficient number of interlocutors within any of the five countries, and political dialogue does not bring substantial change. What is more, the change of the ruling elite (e.g. recently in Kyrgyzstan) does not necessarily depart from the same neopatrimonial pattern of rule.

Until democracy, as well as the rule of law and respect for human rights, begin to be seen as an investment into the future, no domestic or international efforts will bear fruit. The societies must internalise the understanding that respect for and the well-being of every individual will contribute to economic development, diminish conflicts and violence, and boost the support of the international community, thus also bringing in more investments and cooperation. If there is anything the international community can do, it should focus less on the politics and more on the civil society. Within the framework of assistance, not imposition, it should work towards the strengthening of domestic civil society and towards education of people about their basic rights. Most of the hard work to replace the neopatrimonial rule with genuine democracy, however, will have to be done by the countries themselves, in all aspects of life and at all levels of society.

37 Freedom House, Kazakhstan: Democracy Stepping Backwards, Press Release, New York, 2 June 2005, at http://www.freedomhouse.org/media/ pressrel/060205.htm. 